\title{
STRATEGI KOMUNIKASI PEMASARAN PRODUK PERTAHANAN DAN KEAMANAN PT PINDAD (PERSERO)
}

\author{
Jalesita Putri Pramitha ${ }^{1}$, Mohamad Syahriar Sugandi ${ }^{2}$, Asaas Putra ${ }^{3}$ \\ Fakultas Komunikasi dan Bisnis, Jurusan Ilmu Komunikasi, Universitas Telkom \\ Jl. Telekomunikasi No. 1, Kec. Dayeuhkolot, Kab. Bandung, Jawa Barat, 40257, Indonesia \\ No. Telp./HP: ${ }^{1} 085781118196,{ }^{2} 081214157171,{ }^{3} 082115091302$ \\ E-mail:1'jalesita96@gmail.com, ${ }^{2}$ mohsyahriar@gmail.com, ${ }^{3}$ asaasputra@gmail.com
}

Naskah diterima pada tanggal 29 Agustus 2019, direvisi tanggal 4 November 2019, disetujui tanggal 7 November 2019

\section{MARKETING COMMUNICATION STRATEGY OF DEFENSE AND SECURITY PRODUCT PT PINDAD (PERSERO)}

\begin{abstract}
Pindad is an only defense industry that produces weaponry in Indonesia, strives to achieve the autonomy of Indonesia's primary weaponry defense system. In achieving those objectives, Pindad implemented a marketing communication strategy to carry out about introduction and sales activities for the product, spreading the message nationality, and corporate communication activities. The purpose of this research to see how the process of the communications strategy marketing conducted by Pindad. This research used qualitative methods with a case study approach, and data collection was carried through in-depth interviews and observation. The research showed how the planning process, organizing, actuating, and evaluation by Pindad. Marketing Communication by Pindad departs on the segmentation of different audiences, Pindad divides the company's focus on the Marketing Departement for the special segment and the Corporate Communication Department for the general segment. In build marketing communication messages, Pindad includes nationality messages to cultivate the product user and society. The marketing communications is also used the communication business cooperation with the other government, company, and marketing sales directly to the intended segment.
\end{abstract}

Keywords: marketing communication strategy, defense industry, promotion mix.

\begin{abstract}
Abstrak. Pindad merupakan sebuah industri pertahanan yang memproduksi senjata satu-satunya di Indonesia, memiliki sebuah tujuan yaitu mewujudkan kemandirian alat utama sistem persenjataan (alutsista) Indonesia. Dalam mencapai tujuan tersebut Pindad melakukan upaya dalam penerapan strategi komunikasi pemasaran untuk melakukan kegiatan pengenalan dan penawaran produk, menyebarkan pesan kebangsaan, dan kegiatan komunikasi korporat. Tujuan penelitian ini untuk melihat bagaimana proses strategi komunikasi pemasaran yang dilakukan oleh Pindad. Penelitian ini dilakukan dengan menggunakan metode kualitatif dengan pendekatan studi kasus dan pengumpulan data dilakukan melalui wawancara mendalam dan observasi. Hasil penelitian menunjukkan bagaimana proses perencanaan, pengorganisasian, pelaksanaan, dan pengawasan yang dilakukan Pindad. Komunikasi pemasaran yang dilakukan Pindad yang berangkat pada segmentasi khalayak yang berbeda, Pindad membagi fokus perusahaan pada Departemen Pemasaran untuk segmen khusus dan Departemen Komunikasi Korporat untuk segmen umum. Dalam mengemas pesan komunikasi pemasaran, Pindad menyertakan pesanpesan kebangsaan untuk menumbuhkan rasa bangga bagi pengguna produk dan masyarakat. Kegiatan komunikasi pemasaran yang dilakukan juga memanfaatkan komunikasi kerjasama bisnis dengan pemerintah luar, perusahaan lainnya, dan pendekatan langsung dengan segmen yang dituju.
\end{abstract}

Kata kunci: strategi komunikasi pemasaran, industri pertahanan, bauran promosi.

DOI: $10.20422 / j p k . v 22 i 2.673$ 


\section{PENDAHULUAN}

Salah satu elemen dasar dalam upaya pertahanan suatu negara adalah kekuatan militer, peningkatan kualitas dan kuantitas pertahanan terus ditingkatkan oleh pemerintah untuk melakukan pencegahan terhadap segala sesuatu yang mengganggu stabilitas Negara Kesatuan Republik Indonesia (NKRI).

Peran alat utama sistem persenjataan (alutsista) terbilang sangat penting atau vital karena selain untuk sarana pertahanan negara, alutsista juga menjadi bagian penting dalam menjaga keamanan suatu negara dari ancaman-ancaman yang tidak diinginkan. Alutsista merupakan segala bentuk alat serta komponen yang berfungsi sebagai alat pertahanan sebuah negara yang digunakan oleh militer, dalam melakukan proses pengamanan dan mencegah saat terjadinya konflik militer dan konflik yang membahayakan kedaulatan negara dan berguna dalam pengembangan profesionalitas militer suatu negara, karena salah satu ciri tentara yang modern adalah tentara yang dapat memahami berbagai macam persenjataan yang teknologinya terus berkembang setiap waktu (Sudarsono, 2008).

Pembentukan industri persenjataan mandiri ini juga merupakan salah satu langkah yang diupayakan setiap negara termasuk Indonesia sebagai salah satu upaya mempertahankan kedaulatan negara. Karena jika alutsista yang dimiliki ini rusak, kurang, atau lemah, maka akan muncul risiko seperti invasi yang dilakukan negara lain maupun perebutan wilayah yang dapat mengancam pertahanan dan keamanan negara.

Undang-Undang Negara Republik Indonesia Nomor 16 Tahun 2012 Pasal 3 menyebutkan bahwa tujuan dalam penyelenggaraan industri pertahanan adalah mewujudkan industri pertahanan yang profesional, efektif, efisien, terintegrasi, dan inovatif; mewujudkan kemandirian pemenuhan alat peralatan pertahanan dan keamanan; dan meningkatkan kemampuan memproduksi peralatan pertahanan dan keamanan, jasa pemeliharaan yang akan digunakan dalam rangka membangun kekuatan pertahanan dan keamanan yang andal (Kementrian Pertahanan Republik Indonesia, 2012). Oleh karena itu, pengembangan Industri Pertahanan sangatlah penting karena selain membangun kemandirian negara dalam mengamankan wilayah dan memproduksi alutsistanya sendiri.

PT Pindad (Persero) yang selanjutnya disebut Pindad, merupakan salah satu perusahaan atau Badan Usaha Milik Negara (BUMN) yang bergerak di bidang pertahanan dan keamanan negara. Pindad menyediakan kebutuhan produk-produk alat utama sistem senjata untuk mendukung kemandirian pertahanan dan keamanan Negara Republik Indonesia (Pindad, 2017). Berkaitan dengan hasil produk pertahanan dan keamanan maka dalam melakukan kegiatan pemasaran Pindad juga langsung tertuju pada target yang spesifik, dalam hal ini adalah TNI, Polri, maupun institusi sejenis lainnya yang berada di dalam maupun luar negeri. Selain dari segi pemasarannya, Pindad juga menarik untuk dilihat dari sisi publisitas perusahaan. Sebagai perusahaan milik pemerintah, kesan kaku dalam mengemas pesan pastilah tertanam dalam benak masyarakat. Walaupun produk yang dihasilkan merupakan produk khusus dan target pasarnya juga spesifik, namun Pindad tetap memperhatikan citra perusahaan di mata masyarakat umum.

Dalam upaya melakukan inovasi baru dan pengembangan produk, Pindad melakukan beberapa cara dalam menjalin kerjasama dengan pihak luar. Langkahlangkah seperti penandatanganan kontrak kerjasama dengan perusahaan dan negara lain dilakukan oleh Pindad untuk menambah relasi, selain itu juga digunakan untuk meningkatkan kerjasama dalam pengembangan alutsista untuk menunjang terwujudnya kemandirian industri pertahanan Indonesia dan meningkatkan ekspor produk Pindad. Langkah-langkah seperti melakukan penandatanganan nota kesepahaman itu merupakan cara Pindad dalam menjalin kerjasama antarperusahaan, namun selain itu juga pemerintah Indonesia juga melakukan beberapa bentuk kegiatan seperti konferensi atau kegiatan lain yang membahas mengenai pertahanan negara untuk melakukan pendekatan kepada negara lain agar 
terciptanya kerjasama untuk melakukan pengembangan teknologi alutsista Indonesia (Oktora, 2017).

Sebagai industri pertahanan yang memiliki segmen pasar dan produk yang spesifik, maka dalam melakukan kegiatan komunikasi pemasaran juga memperhatikan beberapa faktor seperti keputusan berjenjang dalam sebuah keputusan dalam pembelian produk dan anggaran institusi. Dalam penelitian ini proses strategi komunikasi pemasaran dibahas berdasarkan konsep Proses perencanaan (identifikasi khalayak, menentukan tujuan, merancang pesan, memilih media), pengorganisasian, pelaksanaan (progam yang mendukung tercapaian tujuan, memutuskan melakukan komunikasi pemasaran seperti apa), dan pengawasan. Dalam melakukan berbagai macam bentuk komunikasi pemasaran pada segmen audiens yang dituju karena dalam hal ini Pindad tidak hanya memperhatikan proses pemasaran atau penjualan produk saja, namun juga memperhatikan citra perusahaan dengan memperhitungkan publisitas Pindad di media sosial atau media-media lainnya. Karena kebanyakan perusahaan sejenis (industri pertahanan) hanya memperhatikan kegiatan pemasaran atau penjualannya saja. Pindad beradaptasi dengan zaman yang industrinya sudah mulai memasuki era 4.0, dengan memanfaatkan internet dan media sosial, maka proses komunikasi pemasaran Pindad akan semakin modern.

Berdasarkan beberapa penjelasan tersebut, sebagai industri pertahanan Pindad memiliki sebuah peluang untuk bisa bersaing dengan produk-produk alutsista yang lain. Dengan target audiens yang sudah spesifik atau khusus serta bentuk industri yang istimewa, produk yang diperjualbelikan bukanlah produk konsumsi pada umumnya, Pindad memiliki cara tersendiri dalam menyusun strategi komunikasi pemasaran yang mereka lakukan dalam memperkenalkan perusahaannya. Karena fenomena tersebut, maka peneliti ingin melakukan penelitian dengan sebuah tujuan rumusan masalah, bagaimanakah strategi komunikasi pemasaran yang dilakukan Pindad dalam memasarkan produk pertahanan dan keamanan?

\section{LANDASAN KONSEP}

Strategi komunikasi merupakan panduan dari perencanaan komunikasi (communication planning) dan manajemen komunikasi (communication management) untuk mencapai suatu tujuan. Untuk mencapai tujuan tersebut strategi komunikasi harus dapat menunjukkan bagaimana operasionalnya secara taktis harus dilakukan, dalam arti kata bahwa pendekaran (approaching) bisa berbeda sewaktu-waktu tergantung dari situasi dan kondisi (Effendy, 1986). Berdasarkan penjelasan tersebut, langkah yang dipilih Pindad dalam melakukan kegiatan komunikasi pemasaran dengan tantangan besar dalam memasuki era industri 4.0 tentu saja tidak lepas dari proses strategi pengelolaan komunikasi pemasaran. Melalui proses pengelolaan komunikasi pemasaran, Parag (1999) mengatakan bahwa dalam melakukan manajemen komunikasi sebuah perusahaan harus memperhatikan proses komunikasi yang secara terpadu melalui proses perencanaan, pengorganisasian, pelaksanaan, dan pengawasan agar sebuah tujuan dari perusahaan tersebut dapat dicapai secara maksimal. Parag melihat bahwa sebuah perusahaan dengan jenis industri apa pun tidak akan pernah terlepas dari proses strategi pengelolaan komunikasi pemasaran tersebut, walaupun dalam beberapa pemikiran para ahli lainnya mengatakan atau beranggapan lainnya. Seperti menurut Arief (2019) dalam menyusun sebuah strategi, konsep sebuah strategi itu sendiri terbagi menjadi beberapa bagian seperti perencanaan, pelaksanaan, dan evaluasi.

Dalam teori tersebut dapat dilihat bahwa proses dalam menjalankan sebuah pengelolaan komunikasi pada sebuah perusahaan dalam melakukan langkah perencanaan, pengorganisasian, pelaksanaan, dan pengawasan secara umum. Langkah ini tentu saja bisa menjadi landasan teoretis dalam membahas mengenai proses strategi komunikasi pemasaran yang dilakukan oleh perusahaan strategis seperti Pindad. Sebagai industri pertahanan yang memiliki produk dan target yang fokus, tentu saja langkah POAC (planning, organizing, actuating, 
controlling) dapat dijadikan acuan dalam membahas proses strategi komunikasi pemasaran secara keseluruhan, agar peneliti dapat melihat seperti apa penerapan proses pengelolaan komunikasi pemasaran yang terjadi.

Dari beberapa pendapat tersebut maka dibutuhkan tahapan atau proses komunikasi yang terdiri dari beberapa hal, yaitu: (1) Identifikasi khalayak, mengenali secara jelas target yang akan dituju oleh sebuah perusahaan; (2) Menentukan tujuan, mengetahui tujuan dari sebuah perencanaan perusahaan yang disesuaikan dengan identifikasi khalayak yang telah dibuat; (3) Merancang pesan, sebuah tujuan komunikasi pemasaran haruslah dikemas dengan baik agar pesan tersebut dapat diterima oleh khalayak sesuai dengan yang perusahaan harapkan; (4) Memilih media, perantara yang dipilih perusahaan dalam menyampaikan pesan-pesan komunikasi pemasaran kepada khalayak (Mahasagara, 2019). Morrisan dalam Seskowanti (2016) juga menjelaskan bahwa media digunakan dalam kegiatan komunikasi pemasaran sebagai saluran komunikasi bagi kebutuhan promosi.

Gregorius Chandra dalam Wijaksono (2018) mengatakan bahwa, marketing communication pada dasarnya merupakan bauran alat-alat promosi yang digunakan untuk memberi informasi tentang produk atau jasa yang dihasilkan oleh perusahaan kepada konsumen sehingga tujuan tersebut dapat terwujud. Bauran-bauran tersebut yaitu: (1) Advertising, segala bentuk presentasi dan promosi gagasan, barang atau jasa yang dibayar oleh sponsor yang teridentifikasi; (2) Sales promotion, berbagai macam insentif jangka pendek yang dimaksudkan untuk mendorong percobaan atau pembelian produk dan jasa; (3) Public relation, berbagai macam program yang dirancang untuk mempromosikan atau melindungi citra perusahaan atau produk individualnya; (4) Personal selling, interaksi tatap muka dengan satu atau lebih calon pembeli untuk melakukan presentasi, menjawab pertanyaan, dan mendapat pesanan; (5) Direct marketing, melalui penggunaan surat, telepon, fax, electronic mail, atau internet untuk berkomunikasi secara langsung dengan pelanggan atau untuk mendapatkan respon langsung.

\section{METODE PENELITIAN}

Metode penelitian kualitatif dengan pendekatan studi kasus, sehingga proses dalam sebuah sistem strategi komunikasi pemasaran yang dilakukan dapat dilihat secara mendalam untuk mempelajari latar belakang, keadaan, dan interaksi yang terjadi di Pindad dalam cakupan perencanaan, pengorganisasian, pelaksanaan, dan pengawasan. Paradigma konstruktivistik dipilih oleh peneliti untuk menggambarkan mengenai realita yang terjadi di lapangan dengan teori yang ada dan dapat dikonstruksi ulang, sehingga memunculkan makna-makna yang menggambarkan mengenai fenomena tersebut.

Proses pemilihan informan dipilih menggunakan teknik purposive sampling yang dipilih berdasarkan latar belakang informasi yang dimiliki oleh informan dan keterlibatan informan dengan proses kegiatan strategi komunikasi pemasaran yang dilakukan di Pindad. Peneliti memilih informan kunci yang dianggap memenuhi kriteria sebagai berikut: (1) Mengetahui dan memahami dengan jelas serta mendalam mengenai strategi komunikasi pemasaran produk pertahanan dan keamanan; (2) Menjadi bagian dari proses perencanaan, pengorganisasian, pelaksanaan, dan pengawasan dalam kegiatan komunikasi pemasaran produk pertahanan dan keamanan Pindad; (3) Terlibat dalam proses strategi komunikasi pemasaran yang dilakukan dalam bentuk kerjasama Business to Business (B2B) dan Government to Government (G2G); (4) Bersedia meluangkan waktu bersama peneliti untuk melakukan wawancara. Sesuai dengan kriteria informan kunci tersebut maka peneliti mendapatkan empat informan yang dijadikan sebagai narasumber penelitian ini, yaitu Anton dan Dimas dari Divisi Pemasaran, Komar dari Divisi Komunikasi Korporat, dan Yayat dari Divisi Senjata Pindad. Empat narasumber tersebut dipilih karena dapat menjadi sampel dalam cakupan penelitian yang dilakukan yaitu, komunikasi pemasaran, hubungan masyarakat, dan pihak teknis dalam 
segi produksi alat pertahanan dan keamanan Pindad.

Pengumpulan data dilakukan dengan teknik wawancara mendalam, yaitu dengan wawancara terstruktur. Observasi, peneliti memilih observasi partisipatif dengan metode partisipasi pasif yaitu dalam melakukan penelitian peneliti datang langsung ke tempat terjadinya peristiwa yang akan diteliti atau tempat kegiatan orang yang diamati yaitu di Pindad dengan tidak ikut terlibat dalam kegiatan atau proses perencanaan yang dilakukan Pindad. Untuk teknik pengumpulan data yang terakhir adalah pengumpulan dokumen baik dari proses wawancara yang dilakukan maupun data-data sekunder yang diperoleh peneliti dari studi literatur serta media-media yang digunakan oleh Pindad.

Untuk melakukan keabsahan data, peneliti menggunakan triangulasi data, sumber, dan waktu. Peneliti menggunakan ketiga macam triangulasi tersebut karena dalam melakukan kegiatan penelitian ini peneliti melakukan pengecekan terhadap data wawancara yang diterima dari informan dengan keadaan lapangan yang ada. Selain itu dalam menerima sebuah informasi dari semua informan, peneliti melakukan pengecekan data terhadap keselarasan atau kesamaan informasi yang ada sehingga memunculkan sebuah kesepakatan dalam sebuah validitas data atau informasi. Teknik keabsahan data yang terakhir dilakukan oleh peneliti adalah triangulasi waktu, dalam melakukan penelitian ini peneliti menanyakan pertanyaan yang sama kepada informan dengan periode waktu yang berbeda, cara ini berfungsi untuk melihat keabsahan sebuah informasi yang diberikan oleh informan dalam waktu yang berkala.

\section{HASIL PENELITIAN DAN PEMBAHASAN}

\section{Perencanaan (Planning)}

Berdasarkan penuturan informan terkait dengan identifikasi khalayak, Pindad membagi khalayak mereka menjadi dua yaitu khusus (user) dan umum, dengan cakupan wilayah pemasaran dalam negeri dan luar negeri. Pembagian ini didasari oleh produk yang dihasilkan oleh Pindad, yaitu senjata yang memang tidak bisa dimiliki oleh sembarang orang, hanya beberapa institusi seperti TNI/Polri, institusi sipil yang memiliki izin kepemilikan senjata, dan negara yang memiliki hubungan diplomatik dengan Indonesia yang bisa memiliki senjata buatan Pindad.

Tabel 1

Identifikasi Khalayak

\begin{tabular}{|c|c|}
\hline Jenis Khalayak & Keterangan \\
\hline Khusus (user) & $\begin{array}{l}\text { Institusi pertahanan negara dibawah naungan Kementerian Pertahanan (TNI) } \\
\text { Institusi pemerintahan yang berwenang dalam melakukan pengamanan publik } \\
\text { (Polri) } \\
\text { Institusi pemerintahan yang memiliki izin dalam kepemilikan senjata api sesuai } \\
\text { dengan undang-undang yang berlaku di Indonesia (Kementerian Kehutanan, Sipir, } \\
\text { Badan Intelijen Negara, Perbakin, dll.) } \\
\text { Anggota institusi atau badan pemerintahan yang telah lolos tes untuk mendapatkan } \\
\text { izin kepemilikan senjata (tes keterampilan menembak, psikotes, catatan kriminal, } \\
\text { dan kesehatan) } \\
\text { Negara yang memiliki hubungan diplomatik dengan pemerintahan Indonesia }\end{array}$ \\
\hline Umum & $\begin{array}{l}\text { Masyarakat umum yang membutuhkan informasi mengenai perusahaan maupun } \\
\text { produk dari Pindad (media, akademisi, calon penyedia bahan, dll.) }\end{array}$ \\
\hline
\end{tabular}

Sumber: Olahan Peneliti

Selain target khusus seperti yang sudah dijabarkan, Pindad tetap memperhatikan masyarakat umum sebagai target umum dalam menyampaikan informasi mengenai perusahaan dan general knowledge tentang produk yang Pindad produksi. Lihat Tabel 1 yang menjelaskan mengenai identifikasi khalayak yang dilakukan oleh Pindad.

Setelah mengenal atau memahami khalayak sasaran dan pasar sasaran, maka strategi komunikasi pemasaran yang 
diterapkan oleh perusahaan akan menyesuaikan dengan tujuan komunikasi pemasaran. Sehingga sebelum perusahaan menyusun strategi komunikasi pemasaran, maka perusahaan harus menetapkan tujuan komunikasi pemasarannya terlebih dahulu.

Berkaitan dengan khalayak sasaran Pindad yang dibedakan menjadi dua, maka departemen yang mengurus konsumen pun juga dibagi menjadi dua agar pesan yang disampaikan juga tepat sasaran, maka Pindad membagi fokus strategi komunikasi pemasaran menjadi dua departemen, yaitu pemasaran dan komunikasi korporat (Tabel 2).

Tabel 2

Tujuan Komunikasi Pemasaran Pindad

\begin{tabular}{|c|c|c|}
\hline Departemen & Tujuan & Keterangan \\
\hline Pemasaran & $\begin{array}{l}\text { Meningkatkan penjualan di dalam negeri } \\
\text { maupun luar negeri } \\
\text { Meningkatkan pemahaman user mengenai } \\
\text { produk pertahanan dan keamanan Pindad }\end{array}$ & $\begin{array}{l}\text { Mewujudkan kemandirian alutsista } \\
\text { Indonesia, yaitu semua institusi pertahanan } \\
\text { dan keamanan menggunakan produk } \\
\text { Pindad dalam melaksanakan kewajibannya } \\
\text { menjaga kedaulatan NKRI. }\end{array}$ \\
\hline $\begin{array}{c}\text { Komunikasi } \\
\text { Korporat }\end{array}$ & $\begin{array}{l}\text { Pindad dapat dikenal secara umum } \\
\text { Memberikan pemahaman umum mengenai } \\
\text { perusahaan kepada sasaran umum } \\
\text { Menyebarkan informasi yang mendukung } \\
\text { kebutuhan pemasaran } \\
\text { Menjaga publisitas perusahaan }\end{array}$ & $\begin{array}{l}\text { Corporate Image, yaitu Pindad dikenal } \\
\text { masyarakat sebagai industri pertahanan } \\
\text { yang tetap memperhatikan masyarakat } \\
\text { sekitar dan lingkungan (good corporate). }\end{array}$ \\
\hline
\end{tabular}

Sumber: Olahan Peneliti

Sebagai perusahaan BUMN satusatunya yang bergerak di bidang produksi senjata, tentu saja Pindad ingin menunjukkan dan mengajak masyarakat untuk turut bangga dengan hal ini, karena produk yang diproduksi oleh Pindad tidak hanya digunakan di dalam negeri, namun juga digunakan oleh masyarakat luar negeri. Selain itu, Pindad juga mengunggulkan pesan bahwa alat alutsista ini diproduksi di dalam negeri dan oleh anak bangsa, sehingga pesan lokal konten ini mengajak masyarakat Indonesia untuk turut bangga memiliki Pindad. Langkah tersebut didukung dengan informasi yang menarik dan edukatif, yang tidak hanya diterima oleh user, namun juga masyarakat umum. Hal ini diterapkan pada media-media yang Pindad miliki seperti website, Instagram, Youtube, dan lain-lain. Khusus untuk user dan calon user, Pindad juga mengundang mereka untuk bisa melihat langsung demonstrasi produk yang dilakukan oleh Pindad. Langkah tersebut dilakukan agar user semakin tertarik dan penasaran dengan produk yang Pindad buat, sehingga memunculkan keinginan untuk melakukan pembelian dan kerjasama.

Sebuah perusahaan memerlukan pemilihan media yang tepat agar informasi yang disampaikan dapat diterima oleh khalayak dengan baik. Pindad juga menyampaikan pesan menggunakan medium sebagai salah satu cara untuk menginformasikan, mengingatkan, serta membujuk khalayak. Berdasarkan hasil wawancara dengan informan tersebut dapat diketahui bahwa Pindad mengutamakan medium yang dapat menyampaikan konten pesan yang menarik dan informatif, sehingga dapat lebih mudah dipahami dan melekat di khalayak. Penyampaian pesanpesan perusahaan tersebut diterapkan pada media-media yang Pindad kelola. Media tersebut memiliki kriteria utama yaitu dapat memuat konten atau jenis informasi seperti teks, gambar, dan video dalam satu media. Langkah ini dipilih Pindad agar informasi yang disampaikan kepada khalayak umum dan khusus dapat tersampaikan dengan baik (Tabel 3 dan 4). 
Tabel 3

Perancangan Pesan Komunikasi Pemasaran

\begin{tabular}{cl}
\hline Konten Pesan & \multicolumn{1}{c}{ Keterangan } \\
\hline Khusus & Memberikan pemahaman teknis mengenai produk pertahanan dan keamanan Pindad yang \\
& memiliki kualitas yang baik serta penawaran purna jual yang menarik kepada user. \\
& Pemberian informasi ini diberikan saat melakukan kegiatan pendekatan langsung maupun \\
& saat terlaksananya sebuah event. \\
& Departemen Pemasaran bertanggungjawab dalam menyampaikan pesan ini kepada user. \\
& Memberikan pemahaman umum mengenai gambaran produk pertahanan dan keamanan \\
& Pindad kepada masyarakat umum. \\
& Membangun pesan perusahaan yang modern dan mampu beradaptasi dengan teknologi \\
& dengan memanfaatkan media-media baru dalam proses penyampaian pesan. \\
& Penyampaian pesan ini dilakukan melalui media-media yang akan dipilih dan pada saat \\
& kegiatan yang melibatkan masyarakat umum.
\end{tabular}

Sumber: Olahan Peneliti

Tabel 4

Perencanaan Pemilihan Media dalam Penyampaian Pesan

\begin{tabular}{cl}
\hline Indikator & \multicolumn{1}{c}{ Hasil } \\
\hline Jenis Pesan & $\begin{array}{l}\text { Media yang dipilih dilihat berdasarkan seberapa rumit dan besarnya bobot penjelasan } \\
\text { teknis dalam pesan atau konten yang akan disampaikan. }\end{array}$ \\
Sifat Media & $\begin{array}{l}\text { Kemampuan media dalam meraih semua segmen dan strata sosial. } \\
\text { Dapat memuat konten dengan format teks, visual, dan audio visual. }\end{array}$ \\
Efektivitas & $\begin{array}{l}\text { Informasi yang dibuat dapat diakses dimana saja dan dengan perangkat apa saja. } \\
\text { Informasi yang disampaikan dapat mudah dipahami oleh audiens. }\end{array}$ \\
Interaksional & Media yang digunakan dapat menambah user experience audiens. \\
\hline
\end{tabular}

Sumber: Olahan Peneliti

\section{Pengorganisasian (Organizing)}

Pindad melakukan kegiatan pengorganisasian yang mengarah kepada pembagian tugas dan penempatan SDM dengan baik. Hal ini berguna untuk mencapai target dari masing-masing departemen, oleh sebab itu pengorganisasian yang Pindad lakukan dibagi ke departemen masing-masing. Selain melakukan kegiatan pembagian tanggung jawab dan penempatan SDM secara internal, Pindad juga memanfaatkan bantuan dari pihak eksternal (vendor) maupun production house $(\mathrm{PH})$ dalam membantu saat pelaksanaan eksekusi lapangan dan pembuatan konten digital. Proses akhir dari sebuah pengorganisasian ini adalah untuk melihat prospek user sebagai tanggung jawab Departemen Pemasaran dan Pengelolaan Informasi sebagai tanggung jawab dari Departemen Komunikasi Pemasaran (Tabel 5).

Tabel 5

Strategi Pengorganisasian Pindad

\begin{tabular}{cl}
\hline Departemen & \multicolumn{1}{c}{ Keterangan } \\
\hline Pemasaran & $\begin{array}{l}\text { Tujuan: Melakukan pendekatan dengan khalayak umum (user) } \\
\text { Pengelolaan SDM dalam melakukan kegiatan pemasaran dan penyiapan materi untuk } \\
\text { melakukan pendekatan kepada } \text { user }\end{array}$ \\
& Melakukan koordinasi dengan pihak-pihak berwenang atau terkait saat melakukan kegiatan \\
& yang berhubungan dengan negara lain (pemerintah, kementerian, agen marketing, dll.) \\
& Melakukan koordinasi dengan pihak eksternal (vendor) saat melakukan kegiatan eksekusi \\
& lapangan dalam kegiatan pameran maupun kegiatan lainnya \\
& Hasil: Prospek penawaran produk kepada user
\end{tabular}


Komunikasi Tujuan: Relasi media

Korporat Membentuk tim dalam mengolah informasi yang akan disebarkan melalui media

Menjalin kerjasama dan hubungan yang baik dengan media

Melakukan koordinasi dengan tim eksternal (agency) jika memang membutuhkan bantuan

dalam melakukan pembuatan konten digital yang lebih rumit

Hasil: Publisitas perusahaan

Sumber: Olahan Peneliti

Pindad memang membagi peran dalam penyampaian informasi perusahaan kepada khalayak umum dan khusus. Oleh karena itu, proses organizing dalam strategi komunikasi pemasaran yang Pindad lakukan memang menjadi poin utama yang menjadi fokus perusahaan. Karena apabila dalam proses pengorganisasian ini terjadi suatu masalah, maka informasi yang disampaikan kepada khalayak juga tidak akan sampai. Seperti saat pameran dilakukan, Pindad harus fokus terhadap pesan apa yang akan disampaikan dan kepada target khalayak yang seperti apa, karena output yang dihasilkan untuk tiap target khalayak pastilah berbeda, jika khalayak umum akan menghasilkan peningkatan publisitas perusahaan dan jika khalayak khusus akan menghasilkan peningkatan penjualan. Pengorganisasian yang Pindad lakukan juga tidak hanya membagi fokus kepada target khalayak saja, namun juga penempatan SDM yang diterapkan karena Pindad juga tidak hanya melakukan kegiatan komunikasi pemasaran di dalam negeri saja, namun juga di luar negeri. Oleh sebab itu, proses pengorganisasian ini merupakan langkah yang penting agar perusahaan tetap dapat meraih tujuan perusahaan walaupun dengan target khalayak yang berbeda dan pasar yang luas.

\section{Pelaksanaan (Actuating)}

Pindad memilih media berdasarkan kemudahan audiens dalam menerima pesan tersebut. Jika pesan yang akan diberikan semakin rumit, maka Pindad memilih media visual atau audio visual agar pesan tersebut dapat tersampaikan dengan baik kepada khalayak. Pindad memanfaatkan new media berbasis internet seperti Instagram (@pt_pindad), Facebook (PT Pindad), Website (www.pindad.com), Youtube (PT Pindad Persero) dan media cetak (brosur, katalog, poster) serta alat peraga (mockup) sebagai perantara dalam menyampaikan pesan-pesan pemasaran maupun informasi publik kepada khalayak. Media-media yang memanfaatkan internet sebagai salurannya ini tentu dipilih oleh Pindad karena khalayak dapat dengan mudah mengakses informasi yang mereka inginkan. Alasan lainnya Pindad memilih new media sebagai media utama dalam penyebaran informasi karena Pindad ingin informasi yang diberikan dapat sampai ke seluruh lapisan masyarakat dan menghilangkan strata sosial yang ada di institusi maupun masyarakat umum. Langkah ini tentu saja memiliki keunggulan dalam efisiensi waktu dan biaya yang dikeluarkan untuk menyebarkan informasi kepada target khalayak (Tabel 6).

Tabel 6

Media Pilihan

\begin{tabular}{|c|c|c|}
\hline Jenis Media & Konten & Keterangan \\
\hline Website & $\begin{array}{l}\text { Informasi umum dan informasi yang } \\
\text { lebih rinci mengenai produk }\end{array}$ & $\begin{array}{l}\text { Dapat diakses oleh siapa saja (sasaran khusus } \\
\text { dan umum) untuk mendapatkan informasi yang } \\
\text { mereka perlukan }\end{array}$ \\
\hline Youtube & $\begin{array}{l}\text { Informasi yang lebih rumit } \\
\text { disampaikan jika hanya menggunakan } \\
\text { gambar dan tulisan saja }\end{array}$ & $\begin{array}{l}\text { Informasi dengan jenis audio visual yang dapat } \\
\text { menjelaskan dengan lebih mudah kepada target } \\
\text { khusus maupun umum }\end{array}$ \\
\hline $\begin{array}{l}\text { Instagram dan } \\
\text { Facebook }\end{array}$ & $\begin{array}{l}\text { Informasi singkat dan dapat menarik } \\
\text { minat pembaca untuk melakukan } \\
\text { interaksi lebih lanjut (like, comment, }\end{array}$ & $\begin{array}{l}\text { Informasi berupa gambar dan keterangan } \\
\text { singkat (caption) yang dapat ditautkan dengan } \\
\text { link website untuk memperluas informasi }\end{array}$ \\
\hline
\end{tabular}




\begin{tabular}{cll}
\hline \hline & & \\
Pemberitaan & Share & \\
Online & $\begin{array}{l}\text { Informasi umum yang dibuat untuk Pemberitaan ini dibuat oleh pihak internal } \\
\text { menunjukkan kepada target khusus perusahaan maupun media eksternal untuk }\end{array}$ \\
& $\begin{array}{l}\text { maupun umum tentang kegiatan meningkatkan image perusahaan } \\
\text { perusahaan yang sedang berlangsung }\end{array}$ \\
Mockup & $\begin{array}{l}\text { Model produk yang digunakan untuk Sasaran khusus maupun umum dapat melihat } \\
\text { membantu dalam proses kegiatan langsung secara gambaran nyata tentang produk } \\
\end{array}$ & pemasaran ditawarkan atau dijelaskan \\
\hline
\end{tabular}

Sumber: Olahan Peneliti

Pindad memanfaatkan media-media yang perusahaan gunakan sesuai dengan kebutuhan dan target audiens yang dituju. Untuk informasi publik, Pindad lebih dominan menggunakan media Instagram sebagai perantara penyampaian pesan. Hal ini dipilih karena berkaitan dengan informasi yang akan diberikan serta target audiensnya yaitu user dan masyarakat umum. Pada media Instagram, Pindad mengemas informasi secara singkat, padat dan jelas. Penyampaian informasi tersebut disajikan dalam bentuk gambar dan caption yang mendukung. Selain itu juga, dengan media Instagram ini Pindad dapat melihat respon khalayak melalui comment, like, mention, dan share.

Untuk media sosial seperti Facebook, Pindad memanfaatkan fitur album yang dapat dimanfaatkan oleh Pindad untuk melakukan pengelompokkan foto-foto kegiatan dengan jumlah yang banyak. Untuk media online seperti Youtube, digunakan Pindad untuk melakukan penyampaian informasi audio visual kepada masyarakat. Jenis pesan audio visual merupakan cara penyampaian pesan yang paling efisien, karena kebanyakan orang akan lebih mudah mencerna informasi secara audio visual ketimbang hanya informasi berupa teks saja.

Website dimanfaatkan oleh Pindad sebagai media dalam penyampaian informasi secara detail dan website juga digunakan sebagai press release atau pemberitaan online yang dibuat oleh pihak komunikasi korporat Pindad, selain itu informasi yang ada di website ini juga bisa dimanfaatkan oleh rekan-rekan media sebagai informasi rujukan dalam membuat pemberitaan di media mereka masingmasing. Media-media lainnya seperti brosur, katalog, poster dan mockup dimanfaatkan oleh Pindad dalam menyampaikan informasi kepada user saat melakukan kegiatan pemasaran langsung maupun kegiatan pameran. Media pendukung tersebut berfungsi sebagai perantara agar pesan yang sudah disampaikan dapat kembali diingat (recall) oleh user dan masyarakat umum.
Dalam melakukan
kegiatan pemasaran, Pindad melakukan berbagai macam cara untuk mendekatkan diri kepada user dan menarik minat mereka dalam menggunakan produk pertahanan dan keamanan Pindad. Langkah-langkah yang dipilih Pindad disesuaikan dengan kriteria user dan pasar yang ingin mereka capai. Pindad menggunakan saluran atau pendekatan-pendekatan secara langsung kepada user, hal ini dipilih karena dari jenis perusahaan yang memiliki special product dan special customer, maka beberapa pendekatan ini yang dirasa paling tepat dalam melakukan kegiatan pemasaran.

Sebagai industri strategis, Pindad tentu saja memiliki kewajiban dalam mendukung kebutuhan negara, hal ini disampaikan dengan sebuah tujuan perusahaan yaitu mendukung kemandirian alutsista dan kedaulatan NKRI. Pindad berkerja keras dalam meraih tujuan tersebut, salah satunya dengan menghasilkan produk pertahanan dan keamanan yang memiliki kualitas dan teknologi yang canggih. Namun dalam hal ini, Pindad terus melakukan inovasi bagi pengembangan produk tersebut. Oleh karena itu, Pindad terus menjalin kerjasama dengan pihak-pihak di luar perusahaan baik dalam negeri maupun luar negeri dalam membangun sebuah inovasi dan kegiatan pemasaran, di antaranya adalah dengan:

\section{Pemerintah}

Selain sebagai penentu kebijakan, Pindad juga sangat dibantu pemerintah dalam melakukan kegiatan kerjasama dengan perusahaan maupun negara lain. 
Pemerintah diwakili oleh kementeriankementerian yang ada sangat membuka peluang bagi Pindad untuk melakukan pengembangan tersebut. Salah satunya dengan membuka jalan dalam melakukan kerjasama dengan negara lain. Hubungan diplomatik sangat melekat erat dengan kerjasama yang akan dilakukan oleh Pindad. Karena dari jenis perusahaannya yaitu industri strategis, maka hubungan kerjasama juga tidak bisa dengan sembarang negara maupun perusahaan. Peran duta besar sangat membantu dalam menjalin hubungan dengan negara yang dituju. Pendekatan lobbying juga dilakukan Pindad dalam melakukan pendekatan dengan pihak-pihak pemerintahan. Hubungan antar pemerintah ini diikat dengan sebuah nota kerjasama yang dilakukan kedua pihak, kerjasama ini bisa dikatakan sebagai bentuk Government to Government (G2G).

2. Agen Marketing

Dalam meraih pasar luar negeri, Pindad dibantu oleh pihak ketiga yang berfungsi sebagai agen marketing di negara terkait. Agen marketing ini berperan sebagai representatif Pindad di negara yang mereka pegang. Pindad menganalisis negara-negara mana saja yang memang dirasa memiliki potensi pasar yang baik, dan perusahaan berusaha mencari peluang dengan melakukan kerja sama dengan perusahaan di negara tersebut yang nantinya akan menjadi agen marketing Pindad. Dalam hal ini tentu saja Pindad juga dibantu pemerintah dalam menjalani proses kerja sama ini. Seperti dalam kegiatan regulasi yang harus dipenuhi baik dari Pindad maupun negara yang bersangkutan.

Agen marketing ini diambil dan dipilih untuk mencari informasi tentang pengadaan alutsista yang akan dilakukan di negara tersebut. Agen marketing ini juga digunakan untuk membuka akses Pindad dalam menawarkan produk ke institusi terkait. Pemilihan agen juga dibantu oleh pemerintah maupun duta besar untuk memastikan bahwa perusahaan yang akan dijadikan sebagai agen Pindad ini memiliki potensi yang bagus dan dapat membuka peluang pasar di negara tersebut.

3. Kerjasama Bisnis

Untuk membantu dalam kegiatan pengembangan teknologi, Pindad menjalin kerjasama dengan perusahaanperusahaan luar maupun dalam negeri dengan bentuk kerjasama: (1) Join development, yaitu kerjasama ini dilakukan Pindad dengan pihak terkait pengembangan produk. Hal ini berfungsi untuk saling bertukar pikiran mengenai produk yang akan dibangun dan dikembangkan secara bersama. (2) Join production, yaitu kerjasama ini dilakukan dalam bentuk perakitan produk bersama. Pindad dan perusahaan terkait sama-sama diuntungkan dengan adanya kerjasama ini, karena pada saat perakitan bersama ini pihak Pindad maupun perusahaan terkait sama-sama saling bertukar pikiran dan menyerap ilmu serta teknologi yang dimiliki oleh masing-masing pihak. (3) Join marketing, yaitu kegiatan pemasaran bersama ini menjadi bentuk kerjasama terakhir yang dilakukan oleh Pindad dengan perusahaan maupun negara lainnya. Setelah produk yang dirancang dan dibangun bersama ini telah jadi, maka kedua pihak tersebut bisa memasarkan produk secara bersama. Kegiatan ini bisa disebut juga sebagai kerjasama Business to Business (B2B). 


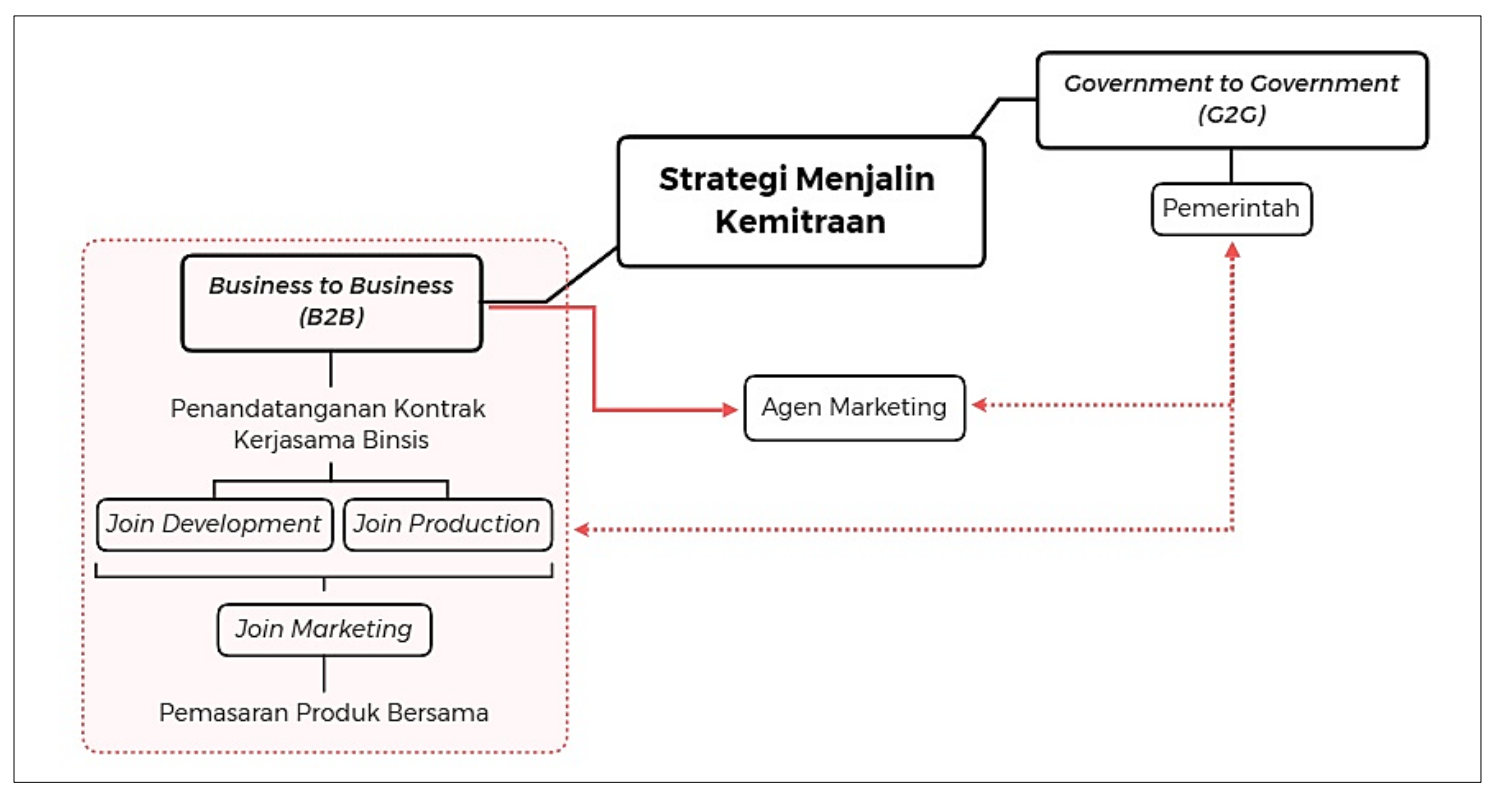

Sumber: Olahan Peneliti

Gambar 1. Strategi Komunikasi dalam Menjalin Kemitraan Pindad

Dalam melakukan bisnis alutsista yang bisa dikatakan produk khusus, maka Pindad juga langsung menargetkan kegiatan pemasaran ini kepada special customer atau user. Untuk melakukan pendekatan kepada institusi terkait, Pindad memilih menggunakan pendekatan langsung dengan memberikan penawaran customer care dalam melakukan kegiatan penawaran produk. Langkah yang dipilih oleh Pindad ini dimaksudkan agar user merasa nyaman dalam melakukan permintaan terkait pemenuhan standar kualitas yang setiap institusi miliki, selain itu cara pendekatan langsung ini dipilih untuk membangun hubungan baik dengan institusi terkait.

Langkah seperti melakukan kegiatan presentasi ke user, demonstrasi, custom produk, after sales merupakan langkahlangkah yang diambil Pindad. Penawaran tersebut akan dilakukan secara bertahap sesuai dengan respon dari user. Kegiatan penawaran langsung yang dilakukan secara formal (presentasi produk) dan informal (diskusi produk) ini dilakukan agar membuka dan menangkap peluang yang akan Pindad ambil untuk melakukan penawaran produk. Karena dalam sebuah diskusi nantinya akan muncul sebuah feedback, dimana dari feedback ini akan terbentuklah sebuah spesifikasi produk yang diinginkan oleh user. Pengguna dapat mengajukan permintaan khusus yang nantinya akan ditindaklanjuti oleh Pindad sebagai custom-made product. Setelah melakukan kegiatan pendekatan langsung, Pindad akan mengundang user tersebut untuk datang ke Pindad dan melihat dan mencoba langsung produk yang akan mereka gunakan nantinya, langkah ini dilakukan untuk menciptakan user experience yang akan lebih meyakinkan user untuk melakukan pembelian produk. Selain kegiatan penjualan, Pindad juga akan menawarkan service tambahan bagi user yang telah membeli produk Pindad, yaitu layanan customer care. 


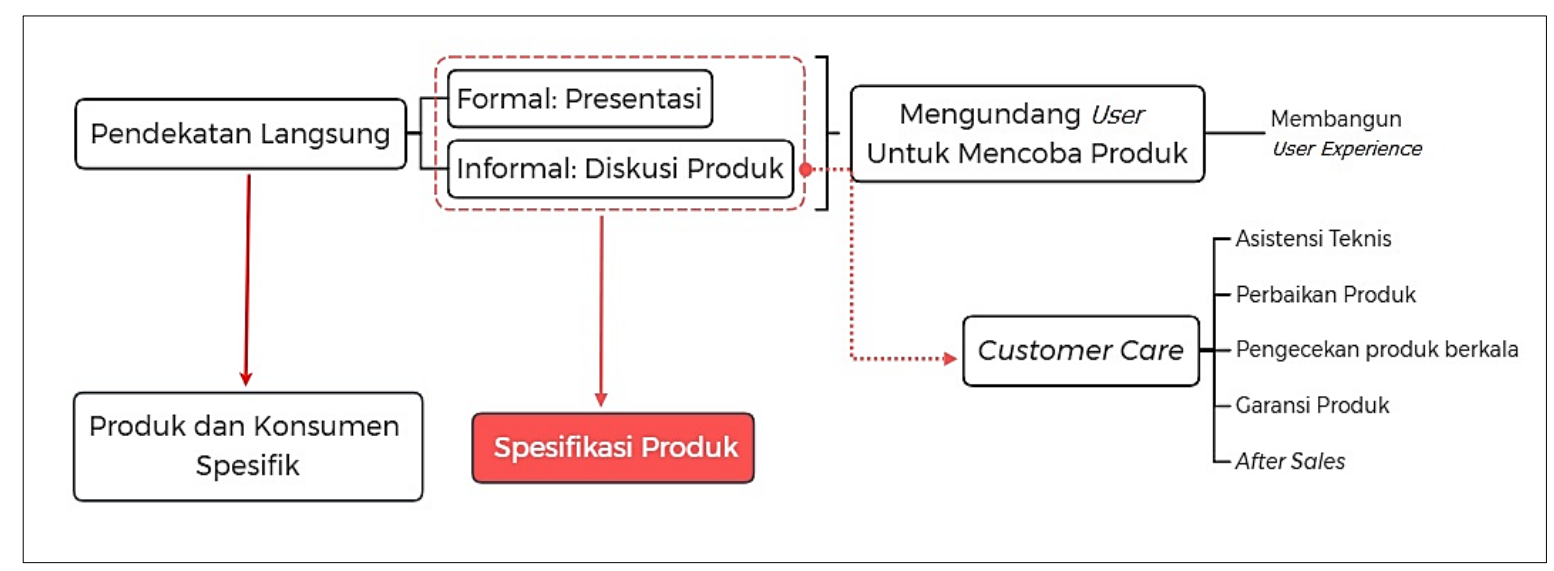

Sumber: Olahan Peneliti

Gambar 2. Strategi Penawaran Produk Pindad

Salah satu langkah yang mendukung kegiatan pemasaran pada sebuah BUMN strategis adalah kegiatan pameran. Dengan cara ini Pindad dapat menunjukkan keberadaannya kepada masyarakat, mungkin untuk industri alutsista kegiatan seperti pameran bukanlah ajang dalam mencari profit seperti produk konsumsi. Berdasarkan pengamatan peneliti di lapangan, Pindad membagi kegiatan pameran ini menjadi dua proyek besar yaitu perintah (mandatory) yang diberikan oleh pemerintah dan dukungan (support) yang diselenggarakan oleh klien khusus Pindad. Selain memperhatikan user Pindad juga tetap memperhatikan masyarakat, dalam kegiatan ini memiliki tujuan akhir untuk menciptakan citra perusahaan yang baik di mata masyarakat, baik yang berhubungan langsung dengan perusahaan maupun yang tidak. Kegiatan seperti melakukan program PKBL (Program Kerja Bina Lingkungan), mengadakan press gathering, memberikan apresiasi kepada user yang berprestasi, maupun perayaan hari ulang tahun Pindad. Program-program seperti ini akan berdampak baik bagi publisitas perusahaan, tidak hanya di media saja namun juga kepada masing-masing orang yang mendapatkan user experience saat mengikuti program-program tersebut. Menjalin kerjasama dengan media juga merupakan salah satu langkah yang diambil Pindad dalam menciptakan citra perusahaan yang baik.

\section{Pengawasan (Controlling)}

Setelah menjalankan semua fungsi komunikasi pemasaran, Pindad melakukan kegiatan pengawasan, hal ini berfungsi untuk melihat hasil dari kinerja yang telah dilakukan dalam tempo waktu mingguan hingga tahunan. Dalam menjalankan fungsi pengawasan, hal ini bisa dilihat dari kegiatan-kegiatan yang dilakukan seperti melakukan pengecekan terhadap kinerja individu dan departemen. Selain itu Pindad juga rutin dalam melakukan pelaporan kegiatan serta progres penjualan, hal ini berdampak positif karena bisa terlihat prospek ke depan untuk masing-masing calon user.

Fungsi pengawasan juga dilakukan oleh Departemen Komunikasi Korporat kepada media. Hal ini berfungsi untuk melihat respon masyarakat terhadap pemberitaan maupun informasi yang telah pihak perusahaan berikan ke khalayak, selain itu pengawasan ini berfungsi untuk meninjau ulang segala bentuk berita atau informasi yang keluar dari perusahaan agar tidak ada kekeliruan maupun berita bohong (hoax) yang tersebar.

Pindad juga melakukan kegiatan audit yang berfungsi untuk menjaga mutu serta kualitas perusahaan dalam menjalankan kegiatan bisnisnya. Audit kepatuhan oleh Satuan Pengawas Internal (SPI) dilakukan untuk meninjau kinerja perusahaan terhadap peraturan perundang-undangan, ada juga pengawasan kualitas oleh Quality Assurance (QA) yang berfungsi untuk mengecek 
produk yang telah diproduksi agar tetap sesuai dengan standar perusahaan, dan tidak lupa juga manajemen resiko yang berfungsi untuk menghindari perusahaan terhadap risiko-risiko yang mungkin terjadi selama proses bekerja maupun risiko perusahaan lainnya. Penjabaran informasi atau data mengenai strategi pengawasan yang dilakukan oleh Pindad (Tabel 7).

Tabel 7

Strategi Pengawasan Pindad

\begin{tabular}{cl}
\hline Indikator & \multicolumn{1}{c}{ Hasil } \\
\hline Evaluasi & Departemen Pemasaran: pengawasan KPI (Key Performance Indicator) per individu yang \\
& dilakukan per minggu, dan pelaporan potential customer yang dilakukan triwulan maupun \\
& tahunan, pelaporan penjualan yang dilakukan tahunan, serta pelaporan kegiatan yang \\
& dilakukan setelah kegiatan selesai. \\
& Departemen Komunikasi Korporat: melakukan pengawasan media yang dilakukan per \\
& minggu, melihat laporan hasil tayang dan mengukur respon khalayak. \\
& Kegiatan audit: dilakukan per semester dengan auditor internal dan eksternal, serta melihat \\
& efektivitas kegiatan yang telah dilakukan.
\end{tabular}

Pencapaian Departemen Pemasaran: jumlah omzet dan permintaan user yang meningkat, sehingga meningkatkan laba tahunan perusahaan.

Departemen Komunikasi Korporat: melihat tanggapan khalayak tentang pemberitaan Pindad yang menghasilkan $90 \%$ respon positif.

Sumber: Olahan Peneliti

Dalam Tabel 7 dijelaskan bahwa sesuai dengan kriteria khalayak yang dimiliki oleh Pindad dan departemen yang bertanggungjawab dalam melaksanakan kegiatan komunikasi pemasaran pada tiaptiap target audiens tersebut, maka Pindad juga membagi sistem pengawasan menjadi dua pembahasan, dalam melakukan pengawasan pemasaran atau penjualan produk pada departemen pemasaran dan pengawasan terhadap media dilakukan oleh Departemen Komunikasi Korporat. Namun, dalam menjalankan fungsi pengawasan tersebut, pimpinan perusahaan tidak melepas tanggungjawab utama pengawasan secara keseluruhan, melainkan menetapkan KPI (Key Performance Indicator) yang dijadikan sebagai pedoman dalam menjalankan fungsi pengawasan secara keseluruhan. Selain itu, Pindad juga rutin dalam menjalankan kegiatan audit. Hal ini berfungsi untuk mengecek kembali standar perusahaan yang dapat dilihat dari tiap-tiap divisi dan departemen.

Langkah pengawasan berguna untuk melihat perkembangan pelanggan potensial dari waktu ke waktu. Hal ini terjadi karena dalam menentukan sebuah keputusan pembelian produk pertahanan dan keamanan, sebuah institusi tidak bisa langsung memutuskan kerja sama yang akan dilakukan karena sifat institusi yang memiliki keputusan berjenjang.

\section{PENUTUP}

\section{Simpulan}

$\begin{array}{ccr}\text { Dalam } & \text { melaksanakan } & \text { kegiatan } \\ \text { komunikasi } & \text { pemasarannya, } & \text { Pindad }\end{array}$ menggunakan dua strategi penanganan yang didasarkan kepada basis khalayak atau konsumen mereka, yaitu: pengguna (user) dan umum. Pengguna adalah konsumen yang menggunakan produk Pindad, sedangkan umum adalah khalayak yang menjadi stakeholders dari Pindad. Pembedaan mengenai kategori umum dan khusus tidak terlepas dari keberadaan produk PT Pindad yang memang tidak diperuntukkan atau diperjualbelikan secara bebas kepada khalayak umum.

Penanganan khalayak dalam kegiatan komunikasi pemasaran produk pertahanan dan keamanan Pindad disesuaikan dengan karakteristik khalayak yang dihadapi, yakni produk spesifik Pindad tidak diperkenalkan kepada publik atau calon konsumen secara 
luas, melainkan spesifik, khas, dan terbatas. Strategi ini dikarenakan jenis produk pertahanan dan keamanan memiliki tingkat strategis politis yang berbeda dengan produk umum lainnya. Alasan strategis dan politis ini terkait dengan keamanan negara, kedaulatan, dan diplomas. Tidak sematamata terkait dengan pertimbangan ekonomis semata.

Berbeda dengan khalayak umum yang juga tidak diposisikan sebagai calon konsumen sehingga kegiatan komunikasi pemasaran bukan dalam konteks pemasaran secara murni juga tidak dapat disamakan dengan publisitas sebagaimana dilakukan perusahaan lain secara umum. Pengelolaan kegiatan komunikasi pemasaran memang ditujukan untuk membangun citra positif dari Pindad, yang membedakan adalah citra positif tidak ditujukan untuk memperkuat brand dalam konteks pemasaran, melainkan lebih kepada menanamkan citra positif terutama nasionalisme dikarenakan PT Pindad adalah perusahaan negara, produsen alutsista satu satunya di Indonesia. Dalam konteks publisitas yang biasa dibangun dalam kontek kehumasan, Pindad juga sedikit berbeda dalam konteks membangun citra perusahaan dalam konteks ekonomis, brand ekuitas secara umum. Pindad memfokuskan kepada penguatan nilai kebangsaan atau nasionalisme kepada masyarakat umum.

Kegiatan komunikasi pemasaran ini dilakukan oleh dua departemen yang ditugaskan berbeda berdasarkan tujuan dan khalayaknya. Pertama adalah Departemen Pemasaran yang menangani khalayak pengguna (user), serta Departemen Komunikasi Korporat yang menjalankan strategi komunikasi di cakupan masyarakat/khalayak umum. Tahapan dalam melaksanakan kegiatan komunikasi pemasaran terbagi atas beberapa tahapan yaitu: Proses perencanaan yang ditujukan kepada user atau pengguna ini memfokuskan pada product knowledge dengan pokok pembahasan spesifikasi, kualitas, dan keunggulan produk yang dikemas secara modern. Perencanaan pemilihan media dalam menyampaikan pesan kepada user juga mempertimbangkan sifat-sifat media, penyampaian pesan yang dilakukan oleh perusahaan haruslah dapat menembus gap strata sosial yang ada di institusi TNI/Polri dan institusi pemerintahan lainnya. Sedangkan untuk segmen khalayak umum, Pindad memfokuskan pembahasan general knowledge kepada masyarakat mengenai perusahaan Pindad dan produk-produk pertahanan dan keamanan yang Pindad produksi. Langkah pengemasan pesan yang dibangun oleh Pindad lebih mengarah kepada pesan nasionalisme yang membuat masyarakat Indonesia bangga terhadap produk lokal yang diapresiasi oleh masyarakat internasional. Perencanaan pemilihan media yang digunakan juga mempertimbangkan beberapa hal terutama dalam segi tampilan, di mana konten yang dimuat pada media tersebut haruslah menarik perhatian masyarakat, agar masyarakat tertarik untuk membaca dan melihat informasi tersebut.

Dalam proses pengorganisasian kepada target khalayak khusus (user) Pindad memfokuskannya kepada Departemen Pemasaran yang melakukan segala bentuk komunikasi antara user dengan perusahaan dalam hal pemberian informasi maupun pelayanan kepada user di dalam negeri maupun di luar negeri dengan tujuan memperluas prospek pengguna produk pertahanan dan keamanan Pindad dan peningkatan omzet perusahaan. Selain itu untuk target khalayak umum proses pengorganisasian ini difokuskan kepada Departemen Komunikasi Korporat yaitu proses menciptakan relasi media yang berfungsi untuk membangun publisitas perusahaan yang baik.

Dalam menjalankan proses pelaksanaan kepada target khalayak khusus, pendekatan langsung dipilih oleh Pindad untuk melakukan kegiatan penjualan kepada user dan melakukan kegiatan penawaran customer care, cara tersebut dipilih karena produk yang ditawarkan juga sudah spesifik dan keputusan pembelian yang berjenjang membuat Pindad memilih lagkah langsung seperti ini. Untuk pemasaran di luar negeri Pindad melakukan kerjasama G2G yang dibantu oleh Pemerintah dan B2B yang 
dibantu oleh agen marketing di setiap negara. Sedangkan untuk target khalayak umum, proses pelaksanaan yang dilakukan oleh Pindad lebih mengarahkan pada penggunaan media dengan pemanfaatan new media berbasis internet serta membangun relasi dengan media eksternal dan menggunakan event sebagai cara untuk mendekatkan diri dengan masyarakat. Langkah ini dilakukan untuk menciptakan user experience bagi masyarakat umum dan membangun citra perusahaan sebagai good corporate yang dinilai peduli terhadap masyarakat sekitar.

Dalam melakukan fungsi pengawasan pada taget khaayak khusus, Pindad melakukan pelaporan potential customer, potensi pasar penjualan di dalam dan luar negeri, dan melakukan review penjualan yang diukur melalui KPI (Key Performance Indicator), pengawasan internal dan pengendalian mutu atau kualitas produk yang secara rutin dilakukan. Sedangkan fungsi pengawasan bagi target umum, Pindad melakukan evaluasi terhadap media, seperti review konten, melihat rekam jejak digital, dan melakukan klarifikasi jika ada informasi yang salah dan tersebar di masyarakat. Dalam menjalankan setiap kegiatan juga dilakukan evaluasi kegiatan dan melihat bagaimana pengaruhnya bagi perusahaan. Langkah-langkah tersebut tentu saja dilakukan untuk melihat pencapaian perusahaan dimana minat baca masyarakat meningkat dan respon masyarakat yang positif terhadap informasi yang Pindad berikan.

\section{Saran}

Perlunya dilakukan penelitian yang lebih mendalam tentang bagaimana proses komunikasi pemasaran yang dilakukan oleh Pindad dalam menjalin kerjasama dengan agen marketing maupun pihak lainnya, guna mengetahui seberapa efektif dan efisien sebuah strategi komunikasi pemasaran yang dilakukan untuk memasarkan produk pertahanan dan keamanan. Perlunya dilakukan penelitian bagaimana implementasi strategi komunikasi pemasaran yang dilakukan untuk memasarkan produk pertahanan dan keamanan pada industri strategis lainnya, sehingga dapat dibandingkan bagaimana strategi komunikasi yang paling efektif.

Berdasarkan hasil penelitian yang telah dilakukan, peneliti memberikan saran kepada Pindad agar melakukan inovasi terhadap proses pemasaran yang akan dilakukan ke depannya, dengan cara memanfaatkan media-media yang akan meningkatkan user experience, seperti membuat simulasi menembak atau memanfaatkan virtual reality untuk lebih mengenal produk pertahanan dan keamanan yang diproduksi oleh Pindad. Saran bagi industri pertahanan lainnya agar dapat mengimplementasikan strategi komunikasi pemasaran seperti yang Pindad lakukan.

\section{DAFTAR PUSTAKA}

Arief, A.N. (2019) Strategi Komunikasi Pemasaran Marketplace B2B dan B2C Berbasis UKM (Studi Analisis pada Platform Marketplace BLANJA.com). Universitas Telkom.

Effendy, O.U. (1986) Dimensi-dimensi Komunikasi. Bandung, Alumni.

Kementrian Pertahanan Republik Indonesia (2012) Undang-undang Republik Indonesia No. 16 Tahun 2012 tentang Industri Pertahanan. [Online]. 2012. Available from: https://www.kemhan.go.id/itjen [Accessed: 3 October 2018].

Mahasagara, S.P. (2019) Strategi Komunikasi Taman Budaya Garuda Wisnu Kencana Sebagai Daya Tarik Wisata Budaya di Bali. Universitas Telkom.

Oktora, M.Y. (2017) Komunikasi Pemasaran PT Pindad (Persero) di Kawasan Asia Tenggara. Jurnal Kajian Komunikasi, Universitas Padjajaran. 5 (2), 190-201.

Parag, D. (1999) Communication Management. Kuala Lumpur, Golden Books.

Pindad (2017) Annual Report PT Pindad (Persero) Tahun 2017. [Online]. 2017. Available from: https://www.pindad.com/annual-report. [Accessed: 3 October 2018].

Seskowanti, D.A. (2016) Bauran Promosi Panser Anoa PT . Pindad. Prosiding Manajemen Komunikasi, Universitas Islam Bandung. 2 (2), 265-272.

Sudarsono, J. (2008) Buku Putih Pertahanan 
Indonesia. [Online]. Jakarta, Departemen Pertahanan Republik Indonesia.

Wijaksono, D.S. (2018) Komunikasi Pemasaran
Ekoturisme Kawah Putih. 4 (2), 130-144. 